the Road Research Board on matters of research connected with problems of roads and road transport overseas and Colonial Research includes some account of work carried out by the Tropical Section of the Road Research Laboratory. There is also a report on the work of the Tropical Products Institute, on surface-active agents derived from sugar, vege- table protein for the relief of malnutrition, the unsaponifiable constituents of banana skin wax, the bleachability of palm oil, constitution of tung oils, the development of new sources of essential oils, physiologically active substances from plants, the biological activity of pyrethrum and the biochemistry and physiology of the pyrethrum plant.

\title{
MANAGEMENT AND SCIENTIFIC MANPOWER
}

$\mathrm{A}$ T a conference at Princeton University during November 1960, which was sponsored by the National Science Foundation, Prof. F. H. Harbison, director of the Industrial Relations Section of Princeton University, described some of the problems his department are investigating in connexion with research on the utilization of scientific manpower*.

Prof. Harbison explained that, despite the advantages offered by industrial research laboratories and their opportunities compared with research departments in academic institutions, the industrial research centres often suffer from schizophrenia. The goals of the corporation and the goals of the professional scientist are not always the same. The scientist. managers of industrial laboratories have, pressing on them, expectations of the corporation for new processes and products and expectations of their subordinate colleagues for professional advancement. Thus, the laboratory managers must face in two directions and understand and speak two languages. This places on them the complex task of engendering enthusiasm in acting as a transmission belt of communication. The top corporation officials do not know how to treat an organization of individuals with sometimes queer but more often indispensable thought processes. Moreover, they find it difficult to measure the contribution of the laboratory to the profit and loss statement.

The industrial research laboratory is under pressure to produce results from new applications of science, and strives to attain status in the scientific community. It must do this in order to attract high-level manpower. The high-status industrial laboratories invariably are those which can claim to be conducting at least some basic research. The laboratories which engage only in applied research are not rated highly in the community, and cannot expect to attract firstclass scientists.

The Government or quasi-Government laboratory is a relatively new organism in American society. It, too, has many assets. It may devote its energies primarily to basic research, or to research of critical importance. Thus, it escapes, in part, the conflict of goals which so often persists in the industrial research centre. It can also command resources for expensive equipment and adequate supporting technical and clerical personnel.

Yet the scientist in this kind of laboratory is not necessarily a 'happy man'. He lives in the most insecure of scientific environments. In many cases he is a 'transient scientist'-on leave for two or three years from a university or an industrial research centre to work on some important project. He may be free to pursue his basic scientific interests, but only for a limited period of time-perhaps insufficient

* Proceedings of a Conference on Academic and Industrial Basic Research, Princeton University, November 1960. (Sponsored by the National Science Foundation.) Pp. vii +87 . NSF $61-39$. (Washington D.C.: Government Printing Office, 1961.) 55 cents. to complete his programme of research. He may become a permanent member of the organization, but there is always the question of how permanent the Government-financed organization may be. Moreover, as a scientist, he may long to be a generator of future scientific manpower. The Government laboratory, however, is not usually a teaching organization, and it is not a good place for the scientist who wants also to be a professor.

The managers of quasi-Government research organizations, therefore, are under pressure to take on a teaching function if they are to achieve renown as permanent homes for the creative scientist. They, like their other organizational counterparts, must develop a managerial system and outlook appropriate to their particular role. The managers of these institutions, as intermediaries between the scientists and Government officials, are faced with unusually frustrating problems of communication. The U.S.S.R. has probably been most successful in building up this kind of organization.

The university has many advantages as an organization to carry on basic research. It also has its problems and shortcomings. In theory, the academic environment offers the scientist free choice of "pathways of research'. 'The university scientist need not be overtly concerned with the application of scientific knowledge to practical problems, nor does the university hire him and tell him what to discover. In the university, the scientist is under no pressure to become a manager, and, most important, the academic scientist has the twin prerequisites of tenure and professorship - a guarantee of freedom of inquiry and a commission to educate a future generation of scientists.

The university environment, however, is in practice not always what it is claimed to be in theory. First of all, teaching takes time, and the scientist may become particularly annoyed with grading papers, attending committee meetings or typing his own letters. More important, he may spend a great deal of time in the applied field as a consultant to Govern. ment or industry. In consequence, he may have little time left for basic research. Finally, the scientist in the university, as in other organizations, may need whole new laboratories costing millions of dollars and employing hundreds of people. At this point, the scientist cannot be a free agent any longer - he must become a scientific organization man. His work must be scheduled and integrated with the efforts of others. The unfamiliar problems of engineering, construction, and supervision of a large staff of technicians bear down on him. He must become a manager of sorts, and a reluctant one, since in the academic community, the 'manager-type' may not be near the top of the totem pole of status. As is often the case, the university research organization is most likely to fail in management of sub-professiona] 
and non-academic personnel-areas in which industry appears to have a comparative advantage.

These observations lead to certain conclusions. First, neither the industrial research centres, the quasi-Government laboratory, nor the university is the ideal organization for basic research; all are undergoing rapid expansion, and all can be improved. All need to examine both their objectives and their operation critically and should make basic studies about 'organizational design' as well as scientific research. For example, the industrial research centre may need to take on some additional activities in fundamental science, or to co-operate more closely with universities in basic research. In return, the universities might consider turning over to industry some of the activities which contribute only marginally to basic research. The quasi-Government organizations need to find a more secure role for themselves and their people. All these organizations draw on the same pool of human capital, and Prof. Harbison emphasizes that it is in the American interest that there be rational thinking about how best to use this precious form of capital.

Secondly, the selection and development of managers in all three types of organization needs more careful attention. Management, in itself, is a kind of profession, in that a successful administrator to-day needs some basic knowledge of principles of organization, human behaviour, motivation and techniques of personnel administration. $\mathrm{He}_{\theta}$ cannot acquire these on the job by experience alone. He must study these systematically, although the concepts of management which are used in administration of corporations are not always appropriate for the administration of laboratories.

The third and final conclusion stems from the other two. The effective selection and development of managerial personnel is dependent on a basic understanding of the nature of research organization, the expectations of different kinds of scientists, and the improvements in design which are necessary for building an effective organization. Only when this is done is there any reliable basis for selection of managers and for the kind of training required to improve their effectiveness.

Systematic analysis of organizational design and managerial development, therefore, is fundamental for effecting better utilization of scientific manpower. To enable this to be done, Prof. Harbison recommends that every sizeable laboratory, whether industrial, Government or university, should have at least one highly competent person devoting his major energies to analysis of organizational and manpower development problems. This man should not be involved in the routine operations of personnel administration. He should report directly to the chief executive officer of the laboratory as a top policy adviser. If possible, he should have had some experience with managerial problems. More important, he should know the laboratory, enjoy the unqualified respect of its scientific personnel, and possess the capacity and interest to analyse human relation. ships systematically with both insight and imagination.

\section{UNIVERSITY OF OXFORD SOUTH CASPIAN EXPEDITION}

$\mathrm{A}$ PARTY from the University of Oxford, with the support of the University of Tehran, made a biological survey of the eastern Caspian coast of northern Iran and the neighbouring Elburz Mountains (long. $52^{\circ}-54^{\circ}$ E., lat. $35^{\circ} 40^{\prime}-37^{\circ}$ N.) during AugustSeptember 1961. The primary objective was to discover the extent and pattern of bird and insect migration through the region.

Detailed observations of bird movements and fluctuations in numbers were made on the Mian Kaleh peninsula, on the Firuz Kuh and Imamzadeh cols, and in the intervening mountain passes and coastal plain by R. W. Arnold, R. S. Bailey, P. P. Feeny and R. J. Olliver of the University of Oxford, and Dr. E. Etemad of the University of Tehran. Altogether, 200 species of birds were recorded from the region during the period of fieldwork. Southerly day-migration through the mountain cols involved a variety of species, but generally small numbers. On the coast, by contrast, both variety and numbers wore far greater, and extensive movements of duck, waders, terns and hirundines were regularly noted. Largest concentrations of passerine night-migrants were found in the hedgerows and woodland of the coastal plain, and included both south-westerly migrants, exemplified by Sylvia borin and $S$. communis, and south-easterly migrants such as Muscicapa parva, Phylloscopus nitidus and Emberiza aureola. This last species has probably not been previously recorded from northern Persia. The significance of the observations is at present being examined, with particular reference to weather, topography and the distribution of the various species.
A small and selective collection of bird skins was made, chiefly comprising wheatears, Oenanthe spp., and yellow wagtails, Motacilla flava, of which at least three races are represented (almost certainly $M . f$. lutea, $M . f$. thunbergi and $M . f$. melanogrisea). In addition, 226 birds of 38 species were trapped with mist-nets and marked with British Museum rings, in the hope of obtaining further information about the directions of migration.

Daily observations of insect migration were carried out by S. L. Sutton, who also took nightly samples with the aid of mercury vapour traps, powered by a portable generator. Many of the Lepidoptera species were definitely migratory, while others were probable migrants. In particular, the butterfly Danais chrysippus chrysippus, previously thought to have a much more southerly distribution, was found in numbers, with some movement to the south. It was seen to come in from the sea, and was also noted moving through the Elburz Mountains at 7,000 ft. The moth Utetheisa pulchella appeared in large numbers on the Caspian coast at the end of August and was afterwards found inland. Many of the other species recorded are well-known migrants of cosmopolitan distribution. A collection of more than 500 specimens of Lepidoptora and other insocts is at present being examinod at the British Museum. The collection includes several little-known species from $9,000 \mathrm{ft}$. in the Elburz Mountains, where mercury vapour trapping was highly successful.

Although botanical collecting was not one of the main objects of the expedition, it was decided to collect a limited number of plants from the region for 